\title{
Economic sanctions outcomes: An information-driven explanation
}

\author{
Mehmet Onder \\ Department of Political Science, \\ Eastern Michigan University, \\ Ypsilanti, MI, USA \\ monder@wayne.edu \\ ORCID 0000-0001-5794-3737
}

\begin{abstract}
Economic sanctions are long-lasting crises between states. Does the exchange of information between the sender and target state impact economic sanction outcomes and durability of economic sanctions? In this article, we answer these questions by presenting a theoretical model leading to expectations regarding the influence of relative capability differentials between sanctioning dyads and political stability of target states on economic sanction outcomes. To account for this, we examine variables related to political, economic, and geographical factors. Our findings indicate that although the relative power is significant, its effect on successful economic sanction outcomes is limited. We also find that political stability in the target state and economic costs borne by the target state due to economic sanctions are two important factors for successful economic sanction outcomes. This shows that successful economic sanction outcomes depend on factors related to target state characteristics.
\end{abstract}

Keywords: economic sanctions outcomes, relative power, political stability.

JEL Classification: F50, F51, F59

\section{INTRODUCTION}

Economic sanctions have become a prevalent foreign policy tool to respond to disputes between states. In the light of increased use and the growing importance of economic sanctions in world politics, it is essential to understand when economic sanctions work and do not work. Economic sanctions are usually applied by powerful states on weaker states for a broad range of issues, including humanitarian violations and support for terrorism. Projecting coercive measures with the use of economic sanctions over global economy should related with political, economic, geographical factors. However, the literature on economic sanctions sheds little light on the role of information about relative power and political stability between sender and target states.

The use of economic sanctions is not only a double-edged sword, but it can also be a counterproductive foreign policy instrument by triggering a series of the interrelated cycle of events between 
sanctioning state and target state, as well as third parties. Economic sanctions can hurt both the sender and the target states. The application of economic sanctions sometimes requires other companion policies, such as introduction of military action. Further, it is not unusual to see economic sanctions lasting longer than expected or ending with unclear outcomes. For example, the United States imposed economic sanctions on Cuba when President Eisenhower placed restrictions on most U.S. exports to Cuba starting from the early 1960s. In February 1962, President Kennedy imposed more comprehensive trade embargo on Cuba. However, it took more than five decades for the American and Cuban governments to announce efforts to normalize relations (Baker, 2014). Although some efforts were made for the reestablishment of diplomatic relations between the U.S. and Cuba, we cannot say that Cuban sanctions were lifted entirely as of today. One of the repercussions economic sanctions on Cuban domestic politics showed itself with the intensification of power under the government of Fidel Castro as the prime minister and later as the president of Cuba.

We also know that when a target state is a major power, economic sanctions rarely work. For instance, Russia, a crucial supplier of oil and gas to the world market, was the target of economic sanctions for more than four decades. When American sanctions were lifted against Moscow in 2012, it had little effect to change the Russian foreign policy behaviour, especially for Ukraine. Within days of Russian annexation of Crimea, the U.S. imposed targeted sanctions together with European Union again (Robert \& Traynor, 2014). The pressure on Russia intensified over time, and other actors, such as Japan, joined the sanctioning coalition later on. The Russian Duma replied with countersanctions, and Russia intervened more in Eastern Ukraine domestic politics. An embargo on its main exports could not return Russia from Crimea nor withdraw from Ukraine. Nor sanctions could not deter Russian behaviours in a desired way of sanctioning coalitions. This example shows that a target state with an abundance of resources not only can endure economic sanctions but also can challenge economic sanctions globally.

These examples show that relative capabilities and domestic politics should play an essential role in economic sanctions outcomes. These factors are important information sources between sender and target state dyads. We believe that information regarding political stability is important for sender state, and information about relative power is important for target state. Then the question becomes, how do information about relative capabilities and domestic political environments affect economic sanction outcomes? We answer this question with information-driven empirical models.

\section{LITERATURE REVIEW}

\subsection{Relative power, political stability, and economic sanction outcomes}

Economic Sanctions are described as policy options between diplomacy and the use of force (Selden, 1999). Helms (1999) argued that sanctions are nonviolent alternatives to the use of military action. For others (Drezner, 2003; Gartzke et al., 2001), economic sanctions serve as a signalling mechanism that conveys the level of determination on the use of military force to the challenger. Economic sanctions are financial tools that are used for issues related to economic, political, social, and military matters between states. The use of economic sanctions is more sophisticated in terms of decision-making and calculating its long term and short-term consequences. Therefore, sender state needs information about political and economic environment about target state. By the same token, target state needs information about sender state relative capabilities. When a sender state is a major power in the international system, then financial penalties imposed by major powers can hurt weak target states severely. We see that major power states tend to use economic sanctions more than ever before in the international system today. 
The increasing interdependent economic network of markets today shrinks the potential autonomy of target state's substitution possibilities during sanctions especially when the power differential between the sanctioning and the target is high. Sanctions are more effective when the cost on the target is high, and the target's ability access markets for goods and services blocked by sanctions is low. A powerful sender endowed with economic, military and political leverages ensures the target's inability to partner with other states, therefore setting it on an advantageous position. Such a delineation of sanctions falls under the instrumentalist paradigm suggesting that sanctions are tools of foreign policy imposed on targets to engender policy change due to economic harms brought by sanctions.

Structural realists (Mearsheimer 2001; Waltz, 1979) believe that any change in the state behaviour is related with the changes in the international system. Similarly, changes in the global economy should have repercussions on state behaviours. States engage in trade wars more than military actions in the $21 \mathrm{st}$ century, and Drezner (2015) calls it as the golden age of economic statecraft. Baldwin (1985) argued that states with higher level of capabilities are more likely to showcase their might through sanctions against actors perceived to be inimical or non-cooperative as alternatives to military actions. Clark and Reed (2005) argued that economic sanctions and the use of force should be used as complements rather than as substitutes. Further, sanctions are believed to more successful since the power reserves endowed by the sender will likely withstand more extended periods, as well as harsher economic and political conditions compared to target states with weak economies (Bapat \& Morgan, 2009). Such conditions are thought to lead to effective sanctions since targets cannot persevere the same amounts of pressure senders can place, sometimes increasingly, due to the possible capability differentials.

Investigations of sanctions have highlighted the importance of signalling in changing target state behaviours (Whang \& Kim, 2015). The more credible the threat or imposition of sanctions, the higher the likelihood of their success. Targets need to believe in the relative power advantage of the sender and the ability of using all available powers in forcing the target to change. This indicates the importance of relative power in its effect on credibility of sanctions that determines a portion of sanctions' outcomes.

Kim (2018) argued that states with higher level of capabilities are more likely to showcase their might through intrusive political tools like sanctions against actors perceived to be inimical or non-cooperative. Further, sanctions are believed to more successful since the power reserves endowed by the sender will likely withstand more extended periods, as well as harsher economic and political conditions compared to weaker targets. Such conditions are thought to lead to effective sanctions since targets cannot persevere the same amounts of pressure senders can place, sometimes increasingly, due to the capability differentials.

Whang (2011) believes that sanctions serve the interests of pressure groups within sender states indicating a relative economic power over targets. This suggests that in countries endowed with higher gross domestic products and financial assets, such as the U.S., sanctions work more effectively given the relative power of the pressure groups supporting them. Therefore, one surmises that the higher the power differential in economic terms, as well as the reach of the country's economic might, the more successful economic sanctions are.

The effectiveness of economic sanctions could be explained by an information-driven approach. Senders threaten and impose sanctions on target states showcasing their relative power advantage sending direct pieces of information about its military, economic and political power in hopes of convincing target governments to back down from the concerned policy. Further, the sender collects information about the stability of the target through available means or penetrating domestic groups/networks within the target. If the information is complete where the target perceives the sender to be powerful and credible and the sender conceives the target as politically unstable, sanctions can have successful outcomes. We depicted informative roles of relative power and political stability between sender and targets states in Figure 1. 


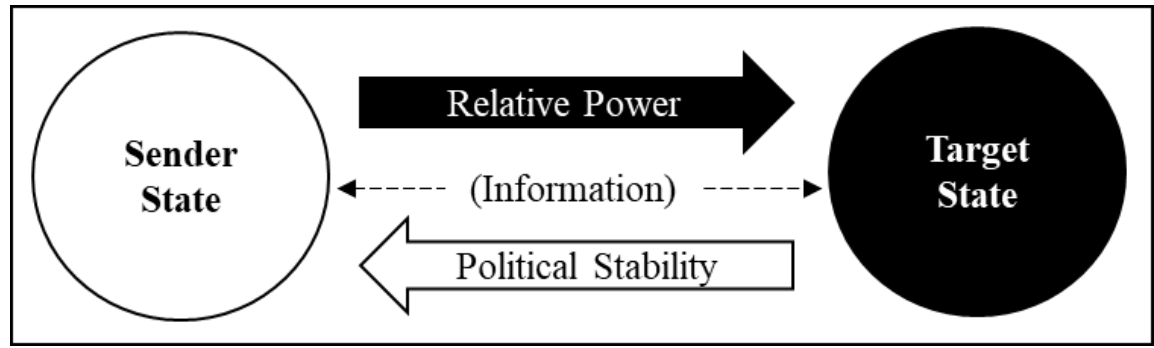

Figure 1. Information flow between sender and target states

Source: compiled by the author

More recent analyses of smart sanctions have highlighted the importance of actors' penetration into the target's political community (McLean \& Radtke, 2018; Connoly, 2016; Major, 2012). Senders with higher access, more frequent and dense networks, in target states have higher likelihoods of success when sanctioning targets compared to sanctions with low access. Episodes involving states with rich political, economic, and social histories have higher chances of being effective compared to sanctions involving senders and targets with little to no history. For instance, the US sanctions on Panama, aiming to destabilize Noriega, were much more effective compared to the American sanctions on Cuba, aiming to destabilize Castro. The American ties with Panama on every level surpassed those with Cuba, giving the US more access to the strongholds of opposition that are likely to destabilize targets' government position in support of the sender.

Empirical analyses of economic sanctions' effectiveness have noted that one of the most successful sanctions are those characterized by the high cost on the target. Economic power differentials, therefore, is likely to play a significant role in sanctions' outcomes. Senders that highly surpass their targets in terms of Gross Domestic Product or economic growth can withstand the harsh economic conditions brought by sanctions compared to less economically endowed targets. Thus, it is expected to observe a higher likelihood of sanctions to be successful if the target state economy cannot endure severe costs of economic sanctions (Bapat et al., 2013; Morgan et al. 2009).

\subsection{Conceptual framework and hypotheses}

Given the importance of exchange of information between states, we believe that the levels of relative capability and political stability are important factors when states decide their policies on economic sanctions. Sender state needs information about political environment of target state, and the target state needs information about relative power capabilities of sender state. We explored the influence of these factors on economic sanction outcomes by controlling factors related with economic, political, and geographical characteristics.

The model constructed in this analysis builds on widely cited factors affecting economic sanctions' outcomes. Those include economic, political, and geographic indicators. The economic indicators include target cost and sender cost. Political variables included political stability, regime type in the sender, and the target actor. Geographic factors included states' proximity and whether the target state is a landlocked nation or not. The first variable, i.e., proximity, explores the influence of geographic remoteness and the economic influence of senders on targets. According to Chaney (2018), proximity is an important element of states' power projection capability. The latter variable, i.e., landlock, explores the target state's sanctions-busting capability. The most explicit country for a landlocked target state is Zimbabwe, which was examined extensively by Galtung's (1967) seminal study discussing why sanctions do not work by focusing on the Rhodesian case study. Besides, Mali and the Central African Republic are among the other 
landlocked target state examples that have been subjected to many unilateral, coalitional, and multilateral sanctions. The inclusion of all such variables ensures the appropriate specification of the model, tests whether any of the included variables moderate the relationship between relative power, the main independent variable, and sanctions' effectiveness, and finally provide the reader with direct estimates on each indicators' explanatory power in the regression analysis performed. Based on the assumptions mentioned above, we hypothesize:

$\mathrm{H}_{1}$ : The higher the relative power difference between sender and target state, the more successful economic sanctions.

$\mathrm{H}_{2}$ : The higher the predictability of the political environment in the target state, the more successful economic sanctions.

The scholarly analysis of economic sanctions' effectiveness linked signaling, an indicator of relative differential, to the odds of sanctions' success (Bapat \& Kwon, 2015; Drezner, 1999). For them, the signaling aspect of economic sanctions is an essential factor. Once senders threaten or impose sanctions, they are showcasing all types of power they possess in an attempt to scare target state actors and make them change their behaviors. Signaling often comes with threats of using a repertoire of powers, soft or hard. Therefore, we assume a positive relationship between the level of relative capability and economic sanction outcomes, and we expect that if power differential is high among actors, signaling is also high leading to more likely effective sanctions.

Target state political environments should also explain a proportion of economic sanctions' outcomes (Allen, 2004). Bolks and Al-Sowayel (2000) mentioned that duration of economic sanctions depends on target state's institutional structure and its political stability. According to Major (2012), the most important predictor for successful economic sanction outcomes is the consideration of domestic politics in the target state. In stable political environments like democracies, institutions, as being information mechanisms, and courses of actions are known to both the target and the sender. This information should be critical for a sender state to analyze the relative capability of a target state and predict the outcome of economic sanctions because sender may utilize such information to its advantage targeting the sanctions to make them more effective by deciding on timing of the sanctions. Further, given the sanctions literature, we expect that unstable political environments should provide less information about sender state capabilities to the sender state for making the odds for sanctions' more effective. As a result, we expect that political stability influence the outcomes of sanctions positively.

\section{METHODOLOGY}

The literature on economic sanctions and relative capabilities suggest that many factors influence economic sanctions outcomes. By applying conventional wisdom and widely cited arguments, we test our hypotheses by using 11 variables that can influence economic sanction outcomes. Figure 2 shows the general specification of restricted and unrestricted models that we used as the base for our empirical analyses. Restricted models include only relative power and political stability variables. Unrestricted models include relative power, target political stability, crisis escalation, issue type, proximity, landlocked, target assistance, sender cost, target cost, sender regime type, and target regime type variables. Figure 2 also shows the final unrestricted model that includes all independent variables. 


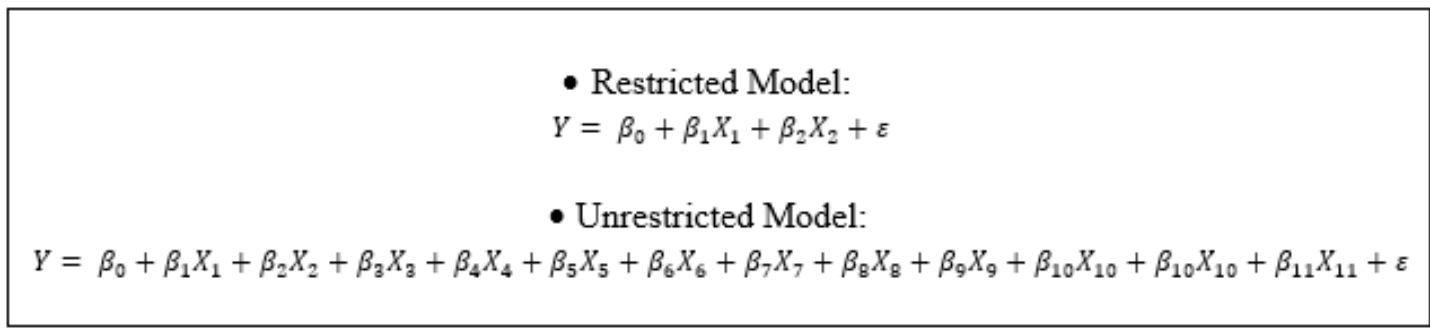

Figure 2. The general illustration of empirical models

Source: compiled by the author

We use ordered probit regression model to test our hypotheses. The conceptual dependent variable is the probability of economic sanctions success. It is an unobserved variable. We operationalized sanctions success probability with policy result variable provided by Hufbauer et al dataset (2007). We pursued the logic of Lam (1990) and Dashti-Gibson et al. (1997) on using policy result variable rather than using success score as our dependent variable. Hart (2000) makes a convincing argument that "the success of an episode is the goal of sanctions research, and it should not be included as part of the dependent variable."

We examined two main independent variables - relative power differentials and target state polity stability. Units of analysis are sender-target dyads in this study. For multilateral economic sanctions, we assumed that there is one sender, which is the main sanctioner. We mainly used cross-sectional dataset provided by Hufbauer et al. (2007). After eliminating cases with missing information, we analysed 188 economic sanctions cases out of 204 cases from 1914 to 2006.

\subsection{Data}

In this study, we combined information from four available datasets. We used (a) economic sanctions data provided by Hufbauer, Schott, Elliot, and Oegg (2007), (b) National Material Capabilities Dataset Version 5.0 provided by the Correlates of War Project29, (c) Geographical Distance dataset30 provided by the CEPII, and (d) Polity IV dataset (Monty et al., 2014) provided by the Center for Systemic Peace31. The domain of this study is HSEO dataset.

\subsection{Sanctions success (policy result) variable}

We used the policy result variable to measure the probability of economic sanctions success as the dependent variable. This variable provided by the HSEO dataset, and it is an ordinal variable measured by four different levels. When an economic sanction policy failed, it is coded as 1 denoting the failed outcome. A score of 2 means unclear outcome, a score of 3 means positive outcome, and a score of 4 means successful outcome. We converted this variable on a 0-3 scale for easier interpretation of regression results. Due to the nature of ordered probit regression models, we interpret this variable as sanctions success probability.

\subsection{Relative power variable}

Relative capabilities play an essential role in shaping foreign policy behaviours in the international system. We used national capability index (composite index of national capability-CINC) scores obtained from National Material Capabilities Dataset v5.0 dataset (1987) provided by the Correlates of War Project for this variable. CINC scores aggregates the six individual indicators (military expenditure, military personnel, energy consumption, iron and steel production, urban population, and total 
population) of national material capabilities into a single value between 0 and 1 per state-year (Singer, 1972). The indicator of the overall relative power variable was calculated by dividing sender CINC score with target CINC score for each sender-target dyad. As for measurement purposes, we then took the natural logarithm of this variable due to its skewed distribution.

\subsection{Political stability variable}

The political stability of the target state is an apparent potential indicator that plays a role in the economic sanction outcomes. Politically unstable regimes can be more vulnerable to economic sanctions. In order to determine whether a regime is stable or not, we used political stability information provided by the HSEO dataset. Political stability variable is an index that captures information about the overall political and economic environment of target state prior to imposition of economic sanctions. Political stability is a normalized continuous variable that can take any rational value between 0 and 1 . A score of 0 means entirely stable, and a score of 1 means a perfectly unstable political environment in a target state.

\subsection{Crisis escalation variable}

During economic sanctions crises, sender states can pursue companion policies together with economic sanctions. The HSEO dataset specified five different companion policies. The code 0 means no companion policy, J means covert action, Q means quasi-military operations, and R means regular military action. We coded this indicator as an ordinal variable in which scales are comprised from 0 to 3 (from no companion policy to regular military action).

\subsection{Issue type variable}

Economic sanctions are usually assumed as the course of action between diplomacy and war. This characteristic of sanctions makes them useful instruments as coercive measures to advance a wide range of foreign policy goals by sender states. States can use for achieving goals related to trading choices or for alliance choices or symbolic reasons. Given the broad nature of issue types for the reasons on the use of economic sanctions, we coded this variable by using HSEO dataset as a binary variable in which a score of 0 means that a sanction case is related with non-security issue(s), and a score of 1 meaning that it is related with security issue(s). For security v. non-security typology, we employed the issue type classification provided by Wallace (Wallace, 2013).

\subsection{Proximity variable}

This variable indicates the geographical proximity between sender and target states. Data for this variable was taken from the GeoDist dataset (Mayer, 2011) provided by the CEPII (Le Centre d'études prospectives et d'informations internationales). The GeoDist dataset provide dyadic level geographical indicators between countries. For the distance between sender and target dyads, we used the air distance (measured in kilometres) between the main cities (economic centre) of the sender and target states. According to the historical record of economic sanctions, the United States has used economic sanctions more than any other country. Therefore, proximity distribution has outliers as the United States is the main sanctioner in most of the cases. To overcome the issue of distribution skewness on regression results, we used the natural logarithm of the distance variable. 


\subsection{Landlocked target variable}

When a country is surrounded only by land, this should constraint its reach to the global market. Countries in this position should be vulnerable to be the target of economic sanctions. In order to explore this observation, we used a binary variable in which a score of 0 indicates being not landlocked, and a score of 1 indicates being landlocked for target states. We used GeoDist dataset for this variable.

\subsection{Assistance to target variable}

Denying foreign assistance can be an essential aspect of economic sanction outcomes when there is an available alternative(s) of financial or trading cooperation for the target state with other nonsanctioning states. Assistance to target can make especially coalitional sanctions useless. Therefore, we want to capture the role of target assistance on the economic sanction outcomes. We used the data provided by the HSEO dataset for this indicator. It is a binary variable, in which a score of 0 means no assistance, and a score of 1 means assistance to the target state.

\subsection{Sender and target cost variables}

Economic costs of sanctions borne by the actors shape their decisions before and during the economic sanction episodes. Therefore, the assessment of sender cost, together with target cost, can play an important role in the economic sanction outcomes. We explored this situation by using ordinal variables. We used HSEO dataset for this variable. In their dataset, Hufbauer et al. (2007) code sender cost variable in four categories where $1=$ net gain, $2=$ little effect, $3=$ modest welfare loss, and $4=$ major loss. We converted sender cost variable into a three-category variable where $0=$ net gain and/or little effect (minor cost), $1=$ modest welfare loss (moderate cost), and $2=$ major loss (major cost). For the target cost variable, Hufbauer et al. provide information as percent of GNP. We converted this information into three categories in which a score of 0 means minor cost (less than $0.5 \%$ ), a score of 1 means moderate level cost (between $0.5 \%$ and 5\%), and a score of 2 means major level cost (an increase of over 5\%). We utilized information provided by Morgan et al. when deciding on category boundaries for the target cost variable.

\subsection{Democratic sender and target variables}

These are binary variables intended to measure the influence of regime type, especially being a democracy, on economic sanction outcomes. We use the Polity IV dataset for this variable. According to Gurr and Jager index (1995), a polity score between -10 and - 6 is considered to be an autocracy, a score between -5 to 5 is considered to be an anocracy, and a score between 6 and 10 is considered to be democracy. We coded regime types separately for sender and target states as binary variables. We code 0 for polity scores five and lower and 1 for any polity score, including and higher than six, as 1 indicating democracy.

\section{EMPIRICAL RESULTS AND DISCUSSION}

Due to the ordinal character of the dependent variable (sanctions policy result), we used ordered probit regression approach to test our hypotheses. Ordered probit regression (OPR) model is a variant of maximum likelihood estimation (MLE) approach that conditions dependent variable on a cumulative probability distribution of each order rather than only $\mathrm{Y}=1$, as in the binary case36. As a result, MLE 
models can help to interpret the influence of each predictor on scales in the dependent variable by presenting predicted probabilities, marginal effects, and conditional probabilities.

We also tested our hypotheses by using a generalized ordinal logistic regression (GOLR) model that was first introduced by Williams (2006). The use of ordinal generalized logit regression approach accounts for heteroskedasticity issue, if any. Furthermore, it helps us to verify our findings from probit regressions. Coefficient scores can be different between probit and logit regressions because they have different definitions.

In order to account for heteroskedasticity, we analysed Pearson's $\mathrm{R}$ and variance inflation factor of each independent variable. We found that multicollinearity is not a problem for the data used in this study. Correlation coefficient scores between most of the variables are lower than 0.2 (except the relationship between crisis escalation and target cost variable is around .49). Usually, multicollinearity is a concern when a correlation score between covariates is over .80. Besides, variance inflation factor score for each independent variable is around 1.60. The threshold for VIF to be a concern is considered when it is over 10 (Wooldridge, 2009). Thus, we confirm that error variances are homoscedastic for our dataset. If there is no heteroskedasticity issue, generalized ordinal logit models (GOLM) should provide almost similar results with the ordinal logit models (OLM). We also run a test for it and found that statistical results are almost identical results between GOLM and OLM models. These tests confirm that we can use homoscedastic regression analyses for empirical tests. See Appendix for detailed results of collinearity tests.

There are two main models used in this study. We analysed each model by ordered probit regression (OPR) and ordinal generalized logistic regression (OGLR). In the first model, we estimate an ordinal model of economic sanction success with a restricted model where there are two right-hand side variables, relative power and political stability. In the second model, we control for other covariates to estimate the economic sanction success. Regression results are presented in Table 1. We also provided mean scores for continuous variables and modal values for ordinal and binary variables together with regression results.

As seen from results presented on Table 1, ordered probit regression (OPR) and generalized ordinal logit regression (GOLR) model regression results present same signs on beta coefficients and statistical significance levels. For both approaches, although coefficient interpretations are not straightforward, we can say that positive coefficients shift the probability of economic sanctions success upward, and negative coefficients shift it downward (Greene, 2010).

For the first hypothesis, we expected e a positive association between sender relative power and successful economic sanction outcomes. Our regression results concur the first hypothesis that relative power differentials between sender and target state should have an important effect on the probability of successful economic sanction outcomes. The relative power variable has a positive coefficient score, and it is statistically significant at varying levels. Therefore, any increase in relative power status between sender and target predicts higher levels of economic sanction success levels better than chance.

For the second hypothesis, we expected to get a positive relationship between target state political environment and successful economic sanction outcomes. We found that target state political stability is a significant predictor for the success of economic sanctions. Against our expectations, our findings show that there is an inverse relationship between target state political environment stability and economic sanction outcomes. Empirical results show that the probability of successful economic sanctions outcomes is higher when there is a stable political environment prior to imposition of sanctions in target state. 
Table 1

Results for the Ordered Probit Regression (OLR) and Generalized Ordinal Logit Regression (GOLR)

\begin{tabular}{|c|c|c|c|c|c|}
\hline Independent Variables & $\begin{array}{c}\text { Model 1.a } \\
(\mathrm{OPR})\end{array}$ & $\begin{array}{c}\text { Model 1.b } \\
\text { (GOLR) }\end{array}$ & $\begin{array}{c}\text { Model 2.a } \\
(\mathrm{OPR})\end{array}$ & $\begin{array}{c}\text { Model 2.b } \\
\text { (GOLR) }\end{array}$ & $\begin{array}{l}\text { Mean }(\mu) \\
\text { Mode }[\mathrm{M}]\end{array}$ \\
\hline Relative Power & $\begin{array}{c}.10 \\
(.04)^{* * *}\end{array}$ & $\begin{array}{c}.17 \\
(.06)^{* * *}\end{array}$ & $\begin{array}{c}.08 \\
(.05) * * \\
\end{array}$ & $\begin{array}{c}.12 \\
(.07)^{* *}\end{array}$ & 2.87 \\
\hline Political Stability & $\begin{array}{c}-.70 \\
(.40) * * \\
\end{array}$ & $\begin{array}{c}-1.17 \\
(.65) * * * \\
\end{array}$ & $\begin{array}{c}-.74 \\
(.42) * * \\
\end{array}$ & $\begin{array}{r}-1.30 \\
(.70) * * \\
\end{array}$ & .15 \\
\hline Crisis Escalation & - & - & $\begin{array}{r}.01 \\
(.09) \\
\end{array}$ & $\begin{array}{r}.02 \\
(.16) \\
\end{array}$ & 0 \\
\hline Issue Type & - & - & $\begin{array}{l}-.00 \\
(.19)\end{array}$ & $\begin{array}{r}.01 \\
.31)\end{array}$ & 1 \\
\hline Proximity & - & - & $\begin{array}{c}-.17 \\
(.10) * \\
\end{array}$ & $\begin{array}{c}-.26 \\
(.17) *\end{array}$ & 8.67 \\
\hline Target Landlocked & - & - & $\begin{array}{l}-.09 \\
(.24)\end{array}$ & $\begin{array}{l}-.13 \\
(.39)\end{array}$ & 0 \\
\hline Assistance (Target) & - & - & $\begin{array}{c}-.43 \\
(.23)^{* *}\end{array}$ & $\begin{array}{c}-.69 \\
(.39)^{* *}\end{array}$ & 0 \\
\hline Sender Cost & - & - & $\begin{array}{l}.05 \\
(.19)\end{array}$ & $\begin{array}{l}-.10 \\
.34)\end{array}$ & 0 \\
\hline Target Cost & - & - & $\begin{array}{c}.28 \\
(.16)^{* *}\end{array}$ & $\begin{array}{c}.49 \\
(.27)^{* *} \\
\end{array}$ & 1 \\
\hline Democracy (Sender) & - & - & $\begin{array}{r}.14 \\
(.30)\end{array}$ & $\begin{array}{r}.26 \\
(.50)\end{array}$ & 1 \\
\hline Democracy (Target) & - & - & $\begin{array}{l}-.12 \\
(.22)\end{array}$ & $\begin{array}{l}-.19 \\
(.37)\end{array}$ & 0 \\
\hline Observations & 188 & 188 & 188 & 188 & \\
\hline Pseudo R ${ }^{2}$ & .013 & .0112 & .040 & .039 & \\
\hline LR Chi-Squared $\left(\chi^{2}\right)$ & 6.76 & 6.01 & 20.11 & 19.36 & \\
\hline Probability $>\chi^{2}$ & .010 & .014 & .044 & .050 & \\
\hline
\end{tabular}

Standard errors in parenthesis

${ }^{*} p<.10$; ${ }^{* *} p<.05$; *** $p<.01$ (one-tailed tests)

Source: own calculation.

We also found that five variables are statistically significant at varying levels as seen in Table 1 . These variables are (a) proximity between sender and target, (b) being a landlocked target, (c) political stability in target, (d) assistance to target, and (e) target cost variables at acceptable significance levels of one-tailed tests. Other remaining variables - crisis escalation, issue type, target landlocked, sender cost, and regime type variables are found as not statistically significant.

In order to understand the change in the probability of economic sanctions success, it is important to discuss marginal effects for a one standard deviation change in the independent variables. For continuous variables, we used marginal probabilities, and for ordinal and binary variables, we used conditional probabilities instead of marginal probabilities. We explain marginal and conditional probabilities of ordered probit regressions in four stages. First, we estimate the predicted probabilities of the unrestricted model and present the results in Table 2. Second, we find the marginal effects of continuous variables and show them in Table 3 . Then, we calculate a series of conditional probabilities for each level difference for ordinal predictor variables and present them in Table 4. Finally, we find conditional probabilities for binary variables and present them in Table 5. When calculating marginal, conditional, and predicted probabilities, we use mean scores for continuous variables, modal values for ordinal and binary variables.

In Table 2, we introduce the predicted probability scores for each level in dependent variable (economic sanction outcome) variable of the unrestricted model (model 2.a). Results show that all 
predicted probabilities are statistically significant at the $99 \%$ level. The probability of an economic sanction episode with a failed outcome $(Y=0)$ is 0.15 , unclear outcome $(Y=1)$ is .27 , positive outcome $(\mathrm{Y}=2)$ is .24 , and successful outcome $(\mathrm{Y}=3)$ is .34 given that predictors are set to their mean scores and modal values. Although it seems that the model predicts successful outcomes better as the orders for the dependent variable increase, the range between lower and upper bounds gets largest when sanctions have successful outcomes (it is $26 \%$ when economic sanctions have successful outcomes, $\mathrm{Y}=3$ ). For other levels, the range of the predicted probability boundaries differs at around 16\%.

Table 2

Predicted probabilities

\begin{tabular}{|l|c|c|c|c|}
\hline \multicolumn{1}{|c|}{$\begin{array}{c}\text { Economic Sanctions } \\
\text { Policy Result }\end{array}$} & Predicted & \multicolumn{2}{|c|}{ Confidence Interval (\%95) } & \multirow{2}{*}{$\begin{array}{c}\text { Significance } \\
\text { Level }\end{array}$} \\
\cline { 3 - 4 } & Probability & Lower Bound & Upper Bound & $* * *$ \\
\hline $\mathrm{Y}=1$ (Failed Outcome) & $15 \%$ & $6 \%$ & $24 \%$ & $* * *$ \\
\hline $\mathrm{Y}=2$ (Unclear Outcome) & $27 \%$ & $19 \%$ & $35 \%$ & $* * *$ \\
\hline $\mathrm{Y}=3$ (Positive Outcome) & $24 \%$ & $17 \%$ & $30 \%$ & $* * *$ \\
\hline $\mathrm{Y}=4$ (Successful Outcome) & $34 \%$ & $21 \%$ & $47 \%$ & - \\
\hline Total & $100 \%$ & - & - & $*$ \\
\hline
\end{tabular}

${ }^{*} p<.10 ; * * p<.05 ; * * * p<.01$

Source: own calculation

In the following tables (Table 3, 4, and 5), we investigate the influence of each variable on economic sanction outcomes in more detail. From regression results in Table 1, we found that there is a positive relationship between relative power and successful economic sanctions. However, this interpretation gives a general idea of the relationship between the two variables. It is crucial to open the black box and see the direction and the effect size of each covariate for each scale in the ordinal dependent variable.

In Table 3, we present the marginal effects of three continuous variables. The direction between these predictor variables and the sanction outcome is very intuitive and informative. There is a positive relationship between successful economic sanction outcomes and the relative power in general. However, given results from the marginal effects below, there is a negative relationship between lower levels of sanction outcome and the relative power variable. Besides, there is a positive relationship at higher levels of the sanction outcome and the relative power variable. We see that sanctions are $3 \%$ more likely to bring out successful outcomes at higher levels for one standard deviation in the relative power variable. Sanctions are $2 \%$ less likely to bring out failed outcomes for higher levels of relative power variable. Table 3 also shows that sanctions are 4\% more likely to bring out failed outcomes and 1\% more likely to cause successful outcomes as the distance between sender and target states increases. Therefore, proximity explains the ineffectiveness of economic sanction outcomes better than effectiveness.

Table 3

Marginal effects for continuous variables

\begin{tabular}{|l|c|c|c|c|c|}
\hline Variables & $\begin{array}{c}\text { Significance } \\
\text { Level }\end{array}$ & $\begin{array}{c}\mathrm{Y}=0 \\
(\text { Failed) }\end{array}$ & $\begin{array}{c}\mathrm{Y}=1 \\
\text { (Unclear) }\end{array}$ & $\begin{array}{c}\mathrm{Y}=2 \\
\text { (Positive) }\end{array}$ & $\begin{array}{c}\mathrm{Y}=3 \\
\text { (Successful) }\end{array}$ \\
\hline Relative Power & $* *$ & -2 & -1 & 0 & 3 \\
\hline Proximity & $*$ & 4 & 3 & 0 & -1 \\
\hline Political Stability & $*$ & 14 & 10 & -2 & -23 \\
\hline
\end{tabular}

$* p<.10 ; * * p<.05 ; * * * p<.01$

Source: own calculation 
The regression results (model 2.a in Table 1) showed that there is a negative relationship between economic sanction outcomes and political stability. A detailed analysis of this relationship with marginal effects in Table 3 indicates that economic sanctions are 23\% less likely to have successful outcomes as the level of political instability in the target state increases. Further, economic sanctions are $14 \%$ more likely to have failed outcomes as the political instability level in target state increases. Moreover, economic sanctions are 10\% more likely to have an unclear outcome as the level of target state political instability increases. In sum, political stability variable has the greatest impact on economic sanction outcomes for variables in this section.

In Table 4, we present a serial of conditional probabilities for three ordinal variables. For predictors in this section, the target cost variable has the most significant impact, especially when the level of cost increases from a moderate level (1) to the major level (2). When target cost variable changes from 1 to 2 , the probability of economic sanctions with a successful outcome is $26 \%$ more likely, and it is $14 \%$ less likely to end up with a failed outcome. Although crisis escalation and sender cost variables are not statistically significant, conditional probabilities show that economic sanctions are $10 \%$ more likely to end up with successful outcomes when sender state introduces covert action accompanied with economic sanctions (from 0 to 1), and economic sanctions are $16 \%$ more likely to turn out to be a successful outcome when the level of sanction cost change from moderate level (1) to major level (2). In sum, results show that sender and target cost variables impact economic sanction outcomes more when it changes from moderate to major levels (from 1 to 2 ) than from minor to moderate levels of cost (from 0 to 1 ).

Table 4

Conditional Probabilities for Categorical (Ordinal) Variables

\begin{tabular}{|l|c|c|c|c|c|}
\hline Variables & $\begin{array}{c}\text { Significance } \\
\text { Level }\end{array}$ & $\begin{array}{c}\mathrm{Y}=0 \\
(\text { Failed }\end{array}$ & $\begin{array}{c}\text { Y=1 } \\
\text { (Unclear) }\end{array}$ & $\begin{array}{c}\text { Y=2 } \\
\text { (Positive) }\end{array}$ & $\begin{array}{c}\text { Y=3 } \\
\text { (Successful) }\end{array}$ \\
\hline Escalation $(0 \rightarrow 1)$ & $\mathrm{n} / \mathrm{a}$ & -6 & 0 & 0 & 10 \\
\hline Escalation $(1 \rightarrow 2)$ & $\mathrm{n} / \mathrm{a}$ & 1 & 0 & 0 & -1 \\
\hline Escalation $(2 \rightarrow 3)$ & $\mathrm{n} / \mathrm{a}$ & 2 & 0 & 0 & -2 \\
\hline Sender Cost $(0 \rightarrow 1)$ & $\mathrm{n} / \mathrm{a}$ & 10 & 4 & -3 & -12 \\
\hline Sender Cost $(1 \rightarrow 2)$ & $\mathrm{n} / \mathrm{a}$ & -8 & -8 & -1 & 16 \\
\hline Target Cost $(0 \rightarrow 1)$ & $* *$ & -5 & -3 & 0 & 26 \\
\hline Target $\operatorname{Cost}(1 \rightarrow 2)$ & $* *$ & -14 & -12 & 0 & 7 \\
\hline
\end{tabular}

$* p<.10 ; * * p<.05 ; * * * p<.01$

Source: own calculation.

In Table 5, we explored the influence of binary variables on sanction outcomes by using conditional probabilities. Modal case for issue type is sanctions related to security issues. Modal case for landlocked target is target states are not landlocked. Modal case for target assistance is there is no foreign assistance to target state during economic sanctions. Modal case for democratic sender is sender states are democracies. Modal case for democratic target is target states are not democracies.

For predictors in this section, the highest impact on sanctions outcome was made by target assistance variable. Results present that sanctions are $12 \%$ less likely to succeed when the target state gets foreign assistance during economic sanctions. Among other variables, sender state regime type accounts more than other variables that, when a sender state has a democratic regime type, sanctions are $8 \%$ more likely to result in successful economic sanction outcomes. 
Conditional Probabilities for Categorical (Binary) Variables

\begin{tabular}{|l|c|c|c|c|c|}
\hline Variables & $\begin{array}{c}\text { Significance } \\
\text { Levels }\end{array}$ & $\begin{array}{c}\mathrm{Y}=0 \\
(\text { Failed })\end{array}$ & $\begin{array}{c}\mathrm{Y}=1 \\
\text { (Unclear) }\end{array}$ & $\begin{array}{c}\mathrm{Y}=2 \\
\text { (Positive) }\end{array}$ & $\begin{array}{c}\mathrm{Y}=3 \\
\text { (Successful) }\end{array}$ \\
\hline Issue Type $(0 \rightarrow 1)$ & $\mathrm{n} / \mathrm{a}$ & 0 & 0 & 0 & 1 \\
\hline Landlocked Target $(0 \rightarrow 1)$ & $\mathrm{n} / \mathrm{a}$ & 2 & 1 & 0 & -3 \\
\hline Target Assistance $(0 \rightarrow 1)$ & $*$ & 11 & 4 & -3 & -12 \\
\hline Democratic Sender $(0 \rightarrow 1)$ & $\mathrm{n} / \mathrm{a}$ & -6 & -3 & 1 & 8 \\
\hline Democratic Target $(0 \rightarrow 1)$ & $\mathrm{n} / \mathrm{a}$ & 2 & 1 & 0 & -3 \\
\hline
\end{tabular}

$* p<.10 ; * * p<.05 ; * * * p<.01$

Source: own calculation.

Results from the tables above show that although the relative power variable is significant and has a positive relationship with successful economic sanction outcomes, its effect size is minimal. Two variables - political stability in target state and economic sanctions cost in target state - are the most influential variables among other variables used in this study. Besides, target stability and target cost variables have almost the same percentage difference for failed and successful outcomes. We see that economic and political factors in the target state are crucial for economic sanction outcomes. These results also suggest that relative capabilities and geographic realities are still important factors that need to be explored more in future studies.

\section{CONCLUSIONS}

\subsection{Discussion}

The analysis demonstrates the importance of relative power in explaining economic sanctions' outcomes. Once power differentials are vast between a sender and target state and known by the sender, the sender's showcase of its might increases deterring the target and resulting in a more cooperative behaviour. On the other hand, if the power differential between sender and target state is small, and when sender and the target have similar relative power profiles, economic sanctions are less likely to work. This is given the withstanding power exhibited by the target. Therefore, relative power constitutes a significant variable of interest that is neglected by many economic sanctions' experts. Often, models of sanctions' effectiveness do not include an explicit exposition on the relative power and rarely include refined measures of the variable yielding misspecified results that have low external validity and value to policymakers.

Various studies (Bell \& Quek, 2018; Jeong and Peksen, 2017, Lektzian \& Souva, 2003) on economic sanction concluded that stable political institutions are positive facilitator of economic sanctions given the quality, clarity, and timely provision of information obtained especially by democratic institutions. It is expected that senders will only impose sanctions if they conceive of their effectiveness, given the power differential provided by information from the target state, which will be better if political stability is in place. This study confirms previous findings and additionally shows that prior political stability is important for the effectiveness of economic sanctions.

When economic sanctions are introduced for target states with politically stable environments, domestic political environment can get unstable after sanctions imposed. According to HSEO dataset, the mean score for instability after sanctions imposition gets two times higher when compared with the mean score before the imposition of sanctions. However, the change mostly happens in stable environments. Especially in democratic regimes, people can criticize government policies without restraints which can 
even cause governments to change. Therefore, sanctions cause to decline the political stability levels in target states. These results confirm Major's arguments on the effectiveness of economic sanctions, as well. This may be due to the exploitation senders undergo when influencing domestic actors and assets inimical to the target government. Further, the sender may better showcase the power differential using internal actors to pressure policy circles within the target to succumb to the desires of the senders through information wars.

The window opened by instability provides senders more opportunities to exploit the strengths and weaknesses of the target and enable their sanctions to work more effectively. For instance, in autocracies endowed with a modicum of stability, the ruler and his government can rally use the rally round the flag effect successfully and can get domestic support easily to the governments' position withstanding economic sanctions. Dictators within stable domestic environments can be gain more power after being a target of economic sanctions. According to Seitz and Zazzaro, rulers in target states can gain more support after sanctions imposition by implementing rally round the flag effect policies against sender state(s).

Consequently, stable political environments provide more access to the sender to manipulate opposition and exploit actors' interests making the odds for successful economic sanction outcomes. The present analysis hypothesizes that unstable political environments provide a window of exploitation where senders with high levels of relative power differentials can penetrate domestic politics in the target providing more resources and pressure to create better odds for sanctions' success. From this point of view, our study supports Dashti-Gibson et al.'s (1997) arguments on the role of political stability on economic sanction outcomes.

The findings of the current analysis on the association between political stability and economic sanctions effectiveness confirms the conventional wisdom within the scholarship on economic sanctions and the importance of regime types. Practitioners of international conflict believed that economic sanctions are effective against target states with stable institutions (Seitz \& Zazzaro, 2019; Cox \& Drury, 2006; Lektzian \& Souva, 2003). Democratic peace theory analysts perceive conflict among democracies as the least favourable outcome making democracies more inclined to solve the crises arising from sanctions, frequently through negotiated settlements (Grauvogel et al., 2017). This analysis provides a mechanism under which political stability influences sanctions' outcomes distinct from that prescribed by democratic peace theorists by focusing on political stability before the imposition of economic sanction. Political stability buttresses the rally round the flag effect, whether in democracies or autocracies, making sanctions less effective, as empirically found in the analysis section above. Therefore, the present study confirms the logic linking political stability and economic sanctions' effectiveness within the international relations literature. In addition, the results of this research confirm earlier arguments concerning the role of economic sanctions domestic instability in target states (Grauvogel et al., 2017; Lucena \& Apolinário, 2016).

We summarized our findings on target state characteristics with a three-dimensional space in Figure 2. The cubic shape shown in the figure was inspired from Kegley and Raymond's (1994) study on the multipolarity of the international system. Here, we demonstrate our findings with four points (A, B, C, and $\mathrm{D}$ ) with respect to target state cost (x-axis), target state political stability (y-axis), and target state national capability index (z-axis). Given the empirical results obtained in this study, at point $A$, the probability of a successful sanction outcome should be higher because the target state's domestic political environment is highly unstable, target state is weak in terms of national capability, and the target state has to bear high costs due to economic sanctions. At point $\mathrm{C}$, the probability of economic sanctions with a failed outcome should be higher because the target state is powerful in terms of national relative power, it 
has a stable political environment and there are lower levels of economic costs due to sanctions. The probability of an economic sanction with a successful outcome should be unclear at points B and D.

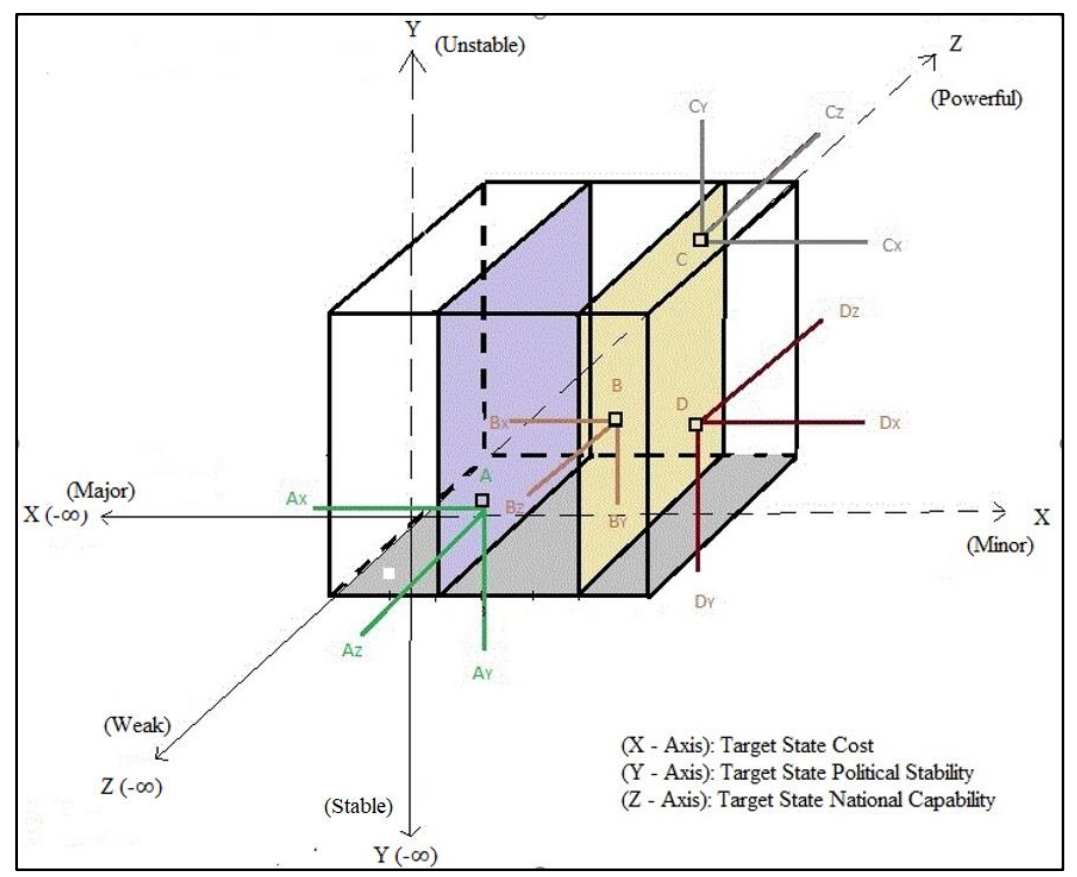

Figure 3. Three Indicators for Successful Economic Sanction Outcomes

Source: compiled by the author.

\subsection{Conclusion}

This analysis tested the theoretical link between relative power capabilities and target state political stability with economic sanctions outcomes. While relative power is statistically significant in determining sanctions outcomes, its effect size on moving sanctions from failure to success seems partial. We also demonstrated the relevance of political stability prior to imposition of sanctions within the target state as a significant factor in determining effectiveness outcomes. Besides, the model verified earlier confirmations concerning the relevance of target cost as an important contributor to sanctions' success.

The effect of relative power on successful economic outcomes is likely to be moderated by political stability in the target. The model results indicated that when target stability is high, sanctions are more likely to work, and when relative power is high, sanctions are more likely to be effective. Therefore, one should expect that in stable political environments, relative power's effect on sanctions should be more substantial compared to politically unstable conditions prior to sanctions. This suggestion points to the need for the development of more conceptual models that capture the interaction of other variables determining failure or success of economic sanctions.

One limitation of the dataset that could have led to the limited effect of relative power is the absence of absolute power provided by the sender. The unit of analysis in the present study only considered the influence of the main sender when an economic sanction case is coalitional, which is untrue in multilateral sanctions where relative power should be the index of relative capabilities for all of the participating sender states. Such a discrepancy is likely to reduce the actual effect of relative power on economic sanctions effectiveness. Future research should better measure relative power to yield more accurate and precise estimates that can inform policymakers and scholars about the potential association between relative power and economic sanctions' outcomes. 


\subsection{Future research}

Future research directions in the economic sanctions' literature should focus more on moderation and mediation effects linking political stability in target states and target cost to economic sanctions effectiveness. Analysts (Onder, 2020; Onder, 2019; Portela, 2014; Hufbauer \& Oegg, 2003) found that the influence of level of political agreement on the use of economic sanctions is an important factor for effective sanctions outcomes. Future research can further explain the effectiveness of sanctions outcomes by uncovering the link between political agreement level on the sanctions use and political stability. While recent research has advanced scholarly knowledge on the conditions under which sanctions are more effective, policymakers are still left without detailed and refined prescriptions on how to proceed when sanctions are not an option. A potential link between political stability and sanctions' effectiveness is the degree of access senders possess to the targets' political, economic, and social establishments. Such access is expected to moderate the relationship positively. Moreover, better measurements of sanctions' effectiveness need to be developed to overcome the modelling and estimation problems plaguing binary, categorical, and ordinal metrics. Therefore, future models of economic sanctions should continue to focus on the target state as the main factor determining whether sanction outcomes are successful or not.

\section{ACKNOWLEDGEMENT}

This research received no specific grant from any funding agency in the public, commercial, or notfor-profit sectors.

\section{REFERENCES}

Allen, S. H. (2004). Rallying cry? Economic sanctions and the domestic politics of the target state. Doctoral dissertation, Emory University.

Baker, P. (2014, December 17). U.S. to Restore Full Relations with Cuba, Erasing a Last Trace of Cold War Hostility. New York Times.

Baldwin, D. A. (1985). Economic statecraft. Princeton University Press.

Bapat, N. A., \& Kwon, B. R. (2015). When are sanctions effective? A bargaining and enforcement framework. International Organization, 69(1), 131-162.

Bapat, N. A., Heinrich, T., Kobayashi, Y., \& Morgan, T. C. (2013). Determinants of sanctions effectiveness: Sensitivity analysis using new data. International Interactions, 39(1), 79-98.

Bapat, N., \& Morgan, T. (2009). Multilateral versus unilateral sanctions reconsidered: a test using new data. International Studies Quarterly, 53(4), 1075-1094.

Bell, M. S., \& Quek, K. (2018). Authoritarian Public Opinion and the Democratic Peace. International Organization, 72(1), 227-242.

Bolks, S. M., \& Al-Sowayel, D. (2000). How long do economic sanctions last? Examining the sanctioning process through duration. Political Research Quarterly, 53(2), 241-265.

Chaney, T. (2018). The gravity equation in international trade: An explanation. Journal of Political Economy, 126(1), 150177.

Clark, D. H., \& Reed, W. (2005). The strategic sources of foreign policy substitution. American Journal of Political Science, 49(3), 609-624.

Connolly, R. (2016). The empire strikes back: Economic statecraft and the securitisation of political economy in Russia. Europe-Asia Studies, 68(4), 750-773.

Cox, D. G., \& Drury, A. C. (2006). Democratic sanctions: Connecting the democratic peace and economic sanctions. Journal of Peace Research, 43(6), 709-722.

Dashti-Gibson, J., Davis, P., \& Radcliff, B. (1997). On the determinants of the success of economic sanctions: An empirical analysis. American Journal of Political Science, 41, 608-18.

Drezner, D. W. (2015). Targeted sanctions in a world of global finance. International Interactions, 41(4), 755-764.

Drezner, D. W. (2003). The hidden hand of economic coercion. International Organization, 57(3), 643-659.

Drezner, D. W. (1999). The sanctions paradox: Economic statecraft and international relations (No. 65). Cambridge University Press. 
Galtung, J. (1967). On the effects of international economic sanctions, with examples from the case of Rhodesia. World politics, 19(3), 378-416.

Gartzke, E., Li, Q., \& Boehmer, C. (2001). Investing in the peace: Economic interdependence and international conflict. International organization, 55(2), 391-438.

Grauvogel, J., Licht, A. A., \& von Soest, C. (2017). Sanctions and signals: How international sanction threats trigger domestic protest in targeted regimes. International Studies Quarterly, 61(1), 86-97.

Greene, William (2014) Models for Ordered Choices. Hess, S., \& Daly, A. (Eds.). Handbook of choice modelling. Edward Elgar Publishing.

Greene, W. H., \& Hensher, D. A. (2010). Modeling ordered choices: A primer. Cambridge University Press.

Gurr, Ted Robert, \& Keith Jaeger. (1995). tracking democracy's third wave with the polity iii data. Journal of Peace Research, 32(4), 469-82.

Hart Jr, R. A. (2000). Democracy and the successful use of economic sanctions. Political Research Quarterly, 53(2), 267284.

Helms, Jesse. (1999). What Sanctions Epidemic?. Foreign Affairs, 78(1), 2-8.

Hufbauer, Gary, Jeffery Schott, Kimberly Elliot, \& Barbara Oegg. (2007). Economic Sanctions Reconsidered, 3rd edition. Washington, DC: The Institute for International Economics.

Hufbauer, G. C., \& Oegg, B. (2003). The European Union as an emerging sender of economic sanctions. Aussenwirtschaft, 58(4), 547.

Jeong, J. M., \& Peksen, D. (2019). Domestic institutional constraints, veto players, and sanction effectiveness. Journal of Conflict Resolution, 63(1), 194-217.

Kegley, C. W., \& Raymond, G. A. (1994). A multipolar peace?: Great-power politics in the twenty-first century (p. 278). New York: St. Martin's Press.

Kim, H. M. (2018). Relationship between economic sanctions and militarized conflict focusing on reciprocal causation. Defence and Peace Economics, 1-18.

Lam, San Ling. (1990). Economic sanctions and the success of foreign policy goals: a critical evaluation. Japan and the World Economy, 2, 239-48.

Lektzian, D., \& Souva, M. (2003). The economic peace between democracies: Economic sanctions and domestic institutions. Journal of Peace Research, 40(6), 641-660.

Lucena Carneiro, C., \& Apolinário Jr, L. (2016). Targeted versus conventional economic sanctions: What is at stake for human rights? International Interactions, 42(4), 565-589.

Major, S. (2012). Timing is everything: Economic sanctions, regime type, and domestic instability. International Interactions, 38(1), 79-110.

Mayer, T., \& Zignago, S. (2011). Notes on CEPII's distances measures: The GeoDist database.

McLean, E. V., \& Radtke, M. T. (2018). Political Relations, Leader Stability, and Economic Coercion. International Studies Quarterly, 62(2), 357-370.

Mearsheimer, J. J. (2001). The tragedy of great power politics. WW Norton \& Company.

Monty G. Marshall, Ted Robert Gurr, Keith Jaggers. (2014). POLITY IV PROJECT: Dataset Users' Manual. Center for Systemic Peace.

Morgan, T. Clifton, Navin Bapat, \& Yoshi Kobayashi. (2014). The Threat and Imposition of Sanctions: Updating the TIES dataset. Conflict Management and Peace Science, 31(5), 541-558.

Morgan, T. C., Bapat, N., \& Krustev, V. (2009). The threat and imposition of economic sanctions, 1971—2000. Conflict Management and Peace Science, 26(1), 92-110.

Onder, M. (2020). Regime Type, Issue Type and Economic Sanctions: The Role of Domestic Players. Economies, 8(1), 2.

Onder, M. (2019). International Economic Sanctions Outcome: The Influence of Political Agreement (Doctoral dissertation, Wayne State University).

Portela, C. (2014). The EU's Use of'Targeted'Sanctions: Evaluating Effectiveness. CEPS Working Documents, 391.

Robert, D. \& Traynor, I. (2014, March 6). US and EU impose sanctions and warn Russia to relent in Ukraine standoff. The Guardian.

Selden, Zachary. (1999). Economic Sanctions as Instruments of American Foreign Policy. Westport, CT: Praeger.

Seitz, W., \& Zazzaro, A. (2019). Sanctions and public opinion: the case of the Russia-Ukraine gas disputes. The Review of International Organizations, 1-27.

Singer, J. David. (1987). Reconstructing the correlates of war dataset on material capabilities of states, 1816-1985. International Interactions, 14, 115-32.

Singer, J. David, Stuart Bremer, and John Stuckey. (1972). "Capability Distribution, Uncertainty, and Major Power War, 1820-1965." in Bruce Russett (ed) Peace, War, and Numbers, Beverly Hills: Sage, 19-48. 
Wallace, G. P. (2013). Regime type, issues of contention, and economic sanctions: Re-evaluating the economic peace between democracies. Journal of Peace Research, 50(4), 479-493.

Waltz, K. N. (1979). Theory of international politics. New York.

Whang, T., \& Kim, H. J. (2015). International signaling and economic sanctions. International Interactions, 41(3), $427-$ 452.

Whang, T. (2011). Playing to the home crowd? Symbolic use of economic sanctions in the United States. International Studies Quarterly, 55(3), 787-801.

Williams, R. (2006). Generalized ordered logit/partial proportional odds models for ordinal dependent variables. Stata Journal, 6, 58-82.

Wooldridge, J. M. (2009). Introductory Econometrics: a modern approach. 4th. Ed. CENGAGE Learning, Canada. 


\section{APPENDIX}

Table A1

Correlation coefficient scores

\begin{tabular}{|c|c|c|c|c|c|c|c|c|c|c|c|c|}
\hline $\begin{array}{c}\text { Variables } \\
\text { (Correlation) }\end{array}$ & $\begin{array}{l}\text { Policy } \\
\text { Result }\end{array}$ & $\begin{array}{l}\text { Relative } \\
\text { Power }\end{array}$ & $\begin{array}{c}\text { Crisis } \\
\text { Escalation }\end{array}$ & $\begin{array}{l}\text { Issue } \\
\text { Type }\end{array}$ & $\begin{array}{c}\text { Target } \\
\text { Proximity }\end{array}$ & $\begin{array}{c}\text { Target } \\
\text { Landlocked }\end{array}$ & $\begin{array}{l}\text { Target } \\
\text { Stability }\end{array}$ & $\begin{array}{c}\text { Target } \\
\text { Assistance }\end{array}$ & $\begin{array}{c}\text { Sender } \\
\text { Cost }\end{array}$ & $\begin{array}{c}\text { Target } \\
\text { Cost }\end{array}$ & $\begin{array}{l}\text { Democracy } \\
\text { (Sender) }\end{array}$ & $\begin{array}{c}\text { Democracy } \\
\text { (Target) }\end{array}$ \\
\hline $\begin{array}{l}\text { Policy } \\
\text { Result }\end{array}$ & 1.00 & & & & & & & & & & & \\
\hline $\begin{array}{l}\text { Relative } \\
\text { Power }\end{array}$ & .18 & 1.00 & & & & & & & & & & \\
\hline $\begin{array}{l}\text { Crisis } \\
\text { Escalation }\end{array}$ & .01 & -.06 & 1.00 & & & & & & & & & \\
\hline $\begin{array}{l}\text { Issue } \\
\text { Type }\end{array}$ & -.06 & -.24 & .34 & 1.00 & & & & & & & & \\
\hline Proximity & -.09 & -.03 & -.11 & -.03 & 1.00 & & & & & & & \\
\hline $\begin{array}{l}\text { Target } \\
\text { Landlocked }\end{array}$ & .02 & .23 & -.02 & .01 & -.06 & 1.00 & & & & & & \\
\hline $\begin{array}{l}\text { Target } \\
\text { Stability }\end{array}$ & -.10 & .16 & -.01 & -.04 & -.16 & .15 & 1.00 & & & & & \\
\hline $\begin{array}{l}\text { Target } \\
\text { Assistance }\end{array}$ & -.12 & .05 & .32 & .13 & -.16 & .05 & .17 & 1.00 & & & & \\
\hline $\begin{array}{l}\text { Sender } \\
\text { Cost }\end{array}$ & -.02 & -.30 & .49 & .32 & -.13 & -.03 & -.05 & .15 & 1.00 & & & \\
\hline $\begin{array}{l}\text { Target } \\
\text { Cost }\end{array}$ & .18 & .29 & .34 & .01 & -.16 & .16 & .08 & .11 & .20 & 1.00 & & \\
\hline $\begin{array}{l}\text { Democracy } \\
\text { (Sender) }\end{array}$ & .05 & 19 & -.17 & -.09 & .43 & -.07 & -.07 & -.19 & -.11 & -.13 & 1.00 & \\
\hline $\begin{array}{l}\text { Democracy } \\
\text { (Target) }\end{array}$ & -.07 & -.25 & -.09 & .17 & -.18 & -.15 & -.09 & -.06 & -.07 & -.19 & -.33 & 1.00 \\
\hline
\end{tabular}

Table A2

Variable Inflation Factor (VIF)

\begin{tabular}{|l|c|c|}
\hline \multicolumn{1}{|c|}{ Variables } & (VIF) & $1 /(\mathrm{VIF})$ \\
\hline Relative Power & 1.68 & .60 \\
\hline Crisis Escalation & 1.59 & .63 \\
\hline Issue Type & 1.54 & .65 \\
\hline Proximity & 1.52 & .66 \\
\hline Target Landlocked & 1.40 & .72 \\
\hline Target Stability & 1.36 & .73 \\
\hline Target Assistance & 1.32 & .76 \\
\hline Sender Cost & 1.29 & .77 \\
\hline Target Cost & 1.20 & .84 \\
\hline Democracy (Sender) & 1.13 & .89 \\
\hline Democracy (Target) & 1.10 & .91 \\
\hline Mean VIF & 1.37 & \\
\hline Note that multiple linear regression model was used for calculations. & & \\
\hline
\end{tabular}


Table A3

Ordinal Logit Regression (OLR) Results

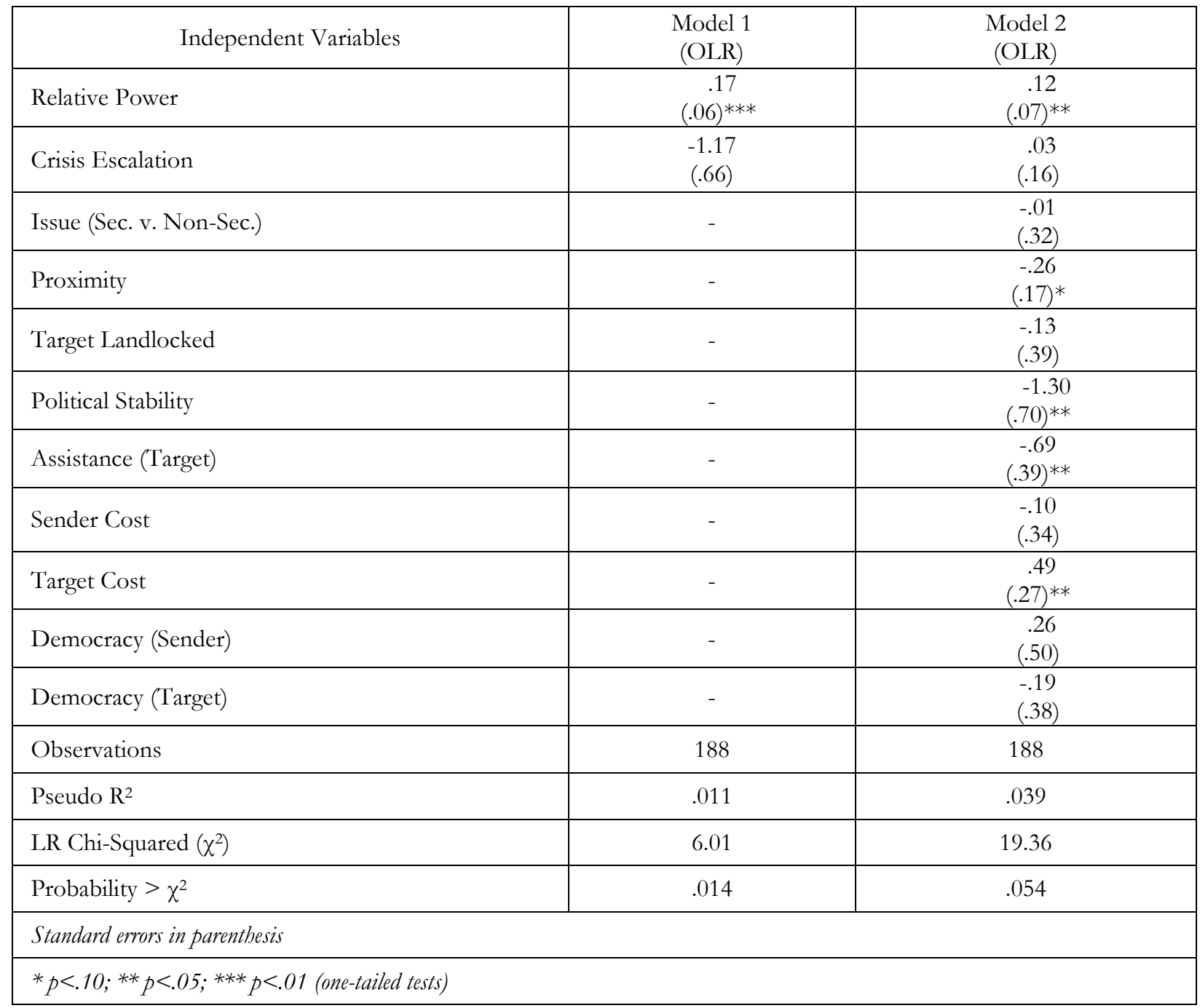

